\title{
仮名読みの獲得過程に対する音韻操作能力の関与
}

\author{
尾川亜希子種村 純
}

\begin{abstract}
要 約：読字を行う際，音韻単位を意識する必要がある．本研究では，小児が仮名文字言語 を学習していく過程における読字能力と音韻操作能力の発達的関連性について検討するため横 断的検討を行った。対象は 3 歳 6 力月から 9 歳 1 力月の健常児 $(n=64)$ で, 仮名読字能力に関 する検查と音韻操作能力（分解・抽出・文字配列）の検査を行った. その結果, 健常児におい て各読字過程の能力が機能的な読字行為を成立させるために, 音韻操作能力の獲得が必要条件 となることが明らかになった。 また, 音韻操作能力も発達に伴い, 課題項目間の関連性が変化 していくことが示された.
\end{abstract}

索引用語：読字過程, 健常児, 音韻操作能力, 獲得過程, 発達

\section{Contributions of Phoneme Operating Ability in Acquisition of Kana Reading}

\author{
Akiko Ogawa, Jun Tanemura
}

\begin{abstract}
It is necessary to be aware of phonemes while reading. In order to examine the contribution of phoneme operating ability in reading, we carried out cross-sectional research concerning the development of reading ability and phoneme operating ability during character acquisition periods. The subjects were normal children of three to nine years old $(n=64)$. They were examined for reading ability of Kana letters (Japanese syllabary) and phoneme operating ability (decomposition, extraction, and letter array). The findings clarified that acquisition of phoneme operating ability is a necessary conditin for acquiring reading function in normal children. It was also shown that the relation between each elemental ability of phoneme operation changes during the developmental processes of the phoneme operating ability.
\end{abstract}

Key words : reading, normal children, phoneme operating ability, acquisition process, development

はじめに

読字には，単語を構成している音韻系列を分析し， その音韻系列の順序および, その音韻の音韻論的構造
の理解に基づいて単語構造を知る技能である音韻操作 能力が含まれている11.

音韻操作能力とは, 読字を行う際に単語同定に至る 視覚的過程, 発話表出のために準備された単語の形式,

川崎医療福祉大学感覚矯正学科：干 701-0193 倉敷市松島 288

Department of Sensory Science, Kawasaki University of Medical Welfare : 288 Matsushima, Kurashiki, Okayama 701-0193

原稿受理：2000 年 11 月 15 日 
音韻構造を空間的に配置された文字群として再構成す ること吕と定義されている. 物井 ${ }^{2}$ が示した仮名の読み 書き過程のモデルによると, 音韻操作能力には, 単語 がいくつのモーラからできているかを認知するモーラ 分解, 各モーラがどういう音であるかを認知する音韻 抽出, 音と仮名の対応という 3 種の能力が含まれてい る.

天野 ${ }^{1}$ は, 文字の習得を単に文字の音価を知ること ではなく, 単語の意味を捨象し, 音的要素に定位し, 単語を構成している様久な語音の中から一定の音韻を 抽出し, 文字記号として定着していく過程であると定 義している.さらに, 音韻操作能力習得の特徵として, 読み書きの中に音声コードから文字コードへ, 文字コ ードから音声コードへ，そのコードを変えるコード変 換過程が含まれている点を挙げている ${ }^{3)}$.

近年，小児の音韻的処理の発達に先立つ条件として 「音韻意識(Phonological awareness)」が注目されてい る ${ }^{4}$. 個々の仮名文字を音韻化することとモーラを意 識することの両機能間には相互作用があり，モーラ意 識が一定程度育つと仮名文字の習得が促進的に作用す る.

以上のように, 音韻操作能力の獲得の程度が仮名読 字の成立に影響しており，音韻操作能力自体も年齢の 進行とともに変化すると考えられる。そこで本研究で は, 健常児の発達における音韻操作能力の獲得過程を 明らかにし, 音韻操作能力と仮名読字能力との発達的 関連性を検討することを目的とした。

\section{対象と方法}

\section{対 象}

保育園, 幼稚園, 小学校に通い, 生活年齢が 3 歳 6 力 月から 9 歳 1 力月の小児（内訳：男児 30 名, 女児 34 名）計 64 名であった。

\section{評価と手続き}

1. 言語心理学的評価

対象児の仮名読字過程の発達を全般的に明らかにす るために, Psycholinguistic assessments of language processing in aphasia (PALPA Kay ら， 1992) ${ }^{5}$ )を参 考にして仮名読字過程に関する課題を作成した。鏡映 文字の弁別, 平仮名と片仮名のマッチング, 仮名単音 の音読, 単音の聴覚文字マッチング, 文字の長さの変 化による仮名単語の音読, 仮名文字列の視覚的語彙判 定，心像性と頻度を統制した仮名単語の音読，仮名非 実在語の音読であった（表 1 ）。

この検查では, 読字情報処理過程を測定することを 目的としている. 成人の読字情報処理モデルを適用す ることによって，小児の文字の情報処理過程を明らか にするために, 本検查の枠組みを使用することとした。

2 . 音韻操作能力検査

対象児の音韻操作能力の獲得水準を明らかにするた めに, 福迫ら6)を参考に仮名単語を使用した次の 3 種 類の検查を作成した。

(1) モーラ分解検査

検査単語は直短音のみ (1), 拗音を含む (1), 長音を 含む (2), 拗長音を含む (2), 促音を含む (2), 撥音を含 む(1)の $3 \sim 5$ モーラの計 9 単語とした.丸を 6 個描い

表 1 PALPA の読解モデルによる仮名読字検査手続き

\begin{tabular}{|c|c|c|}
\hline 読解過程 & 項目 & 手続き \\
\hline \multirow[t]{6}{*}{ 視覚的正書法分析 } & 鏡映文字 & $\begin{array}{l}\text { 印刷された文字 (平仮名と片仮名) から, } \\
\text { 正しい形態の文字に印をつける. }\end{array}$ \\
\hline & 平仮名 $\rightarrow$ 片仮名 matching & $\begin{array}{l}\text { 文字を呼称することなく平仮名目標語と } \\
\text { 同じ読みの片仮名に印をつける. }\end{array}$ \\
\hline & 片仮名 $\rightarrow$ 平仮名 matching & $\begin{array}{l}\text { 文字を呼称することなく片仮名目標語と } \\
\text { 同じ読みの平仮名に印をつける. }\end{array}$ \\
\hline & 音読：単音 & 平仮名，片仮名で書かれた単音の音読 \\
\hline & 単音の聴覚文字 matching & $\begin{array}{l}\text { 与えられた } 4 \text { 単音（平仮名）から, 口頭 } \\
\text { で提示された音に相当する文字を選択. }\end{array}$ \\
\hline & 音読：文字の長さ & 3 ～6 文字の実在語を音読. \\
\hline 正書法入力レキシコン & 視覚的語彙判定 & $\begin{array}{l}\text { 印刷された実在語と非実在語の中から実 } \\
\text { 在語に印をつける. }\end{array}$ \\
\hline 意味システム & 音読：心像性×頻度 & 心像性と頻度を統制した実在語を音読. \\
\hline 正書法－音韻変換 & 音読：非実在語 & 3～6 文字の非実在語の音読. \\
\hline
\end{tabular}


たカードとおはじき 10 個を与えた.検査単語を口頭で 与え，その構成モーラ数だけおはじきを置かせた。

(2)モーラ抽出検査

・/ ka/の有無と位置：語頭 (1)・語中 (1)・語尾 (1)の いずれかに $/ \mathrm{ka} /$ が含まれている単語 $(3$ モーラ）と $/ \mathrm{ka} /$ が含まれていない単語 ( 3 モーラ： 2 単語) の計 5 単語を用いた。丸を 3 個描いたカードとおはじき 1 個を与えた。検查語を口頭で与え, $/ \mathrm{ka} /$ の有無を聞き, 3 モーラ中の $/ \mathrm{ka} /$ の位置におはじきを置かせた.

- 単語内文字の位置 : 直短音のみ (1), 拗音を含む (1)，長音を含む(2), 撥音を含む(1)の $4 \sim 5$ モーラの 計 5 単語を用いた。丸を 6 個描いたカードとおはじき 1 個を与えた。検査単語とその単語を構成している 1 モーラを口頭で与え，単語内の文字の位置に扔はじき を置かせた。

・語頭音抽出：口頭で語頭音を与え, その音で始ま
る絵を選ばせた。 2 〜 モーラ単語を使用し， 3 者択 一式で計 10 題とした. 3 つの絵が描かれたカードを使 用した。

\section{3 . 仮名文字配列検查}

直短音のみ (1), 拗音を含む (1), 長音を含む (1), 促 音を含む(1), 撥音を含む(1)の $3 \sim 5$ モーラの計 5 単 語を用いた。検査語と検査語に無関係な仮名 2 文字を 加えた文字カードを与えた。検査語を口頭で与え, 相 当する単語を作成させた。

\section{分析方法}

小児の読字能力と音韻操作能力の発達における相互 関係を明らかにするために, 各年齢群の正答率を比較 した。さらに年齢間の発達差を明確にするために, Mann-Whitney のU検定を用いた。 また, 音韻操作能 力に関する各検查に関して, 各年齢における機能的関 連性を検討するため, 項目間の相関係数を求めた.

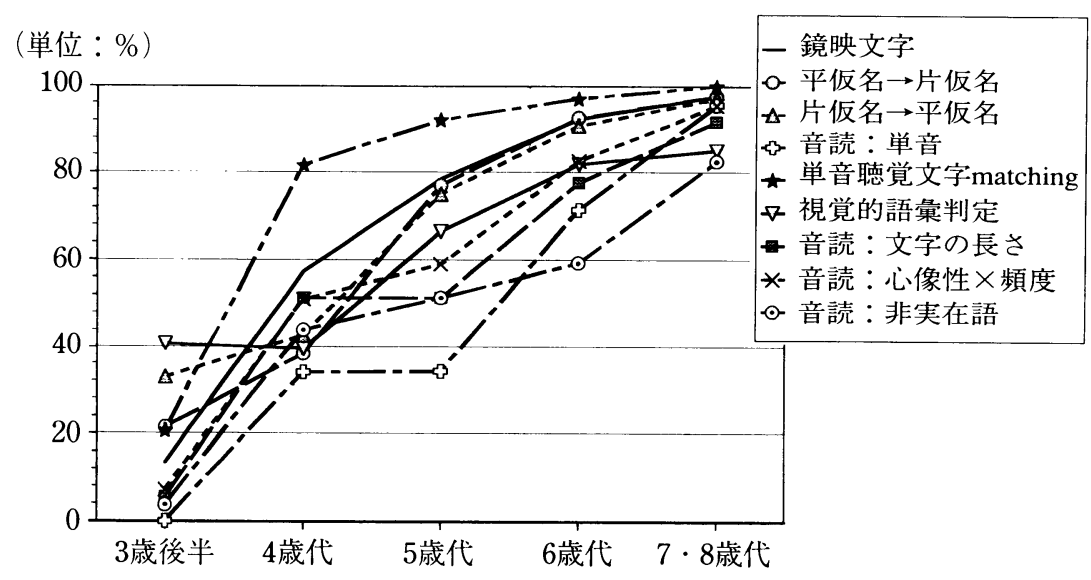

図 1 仮名読字検査における年齢別平均正答率

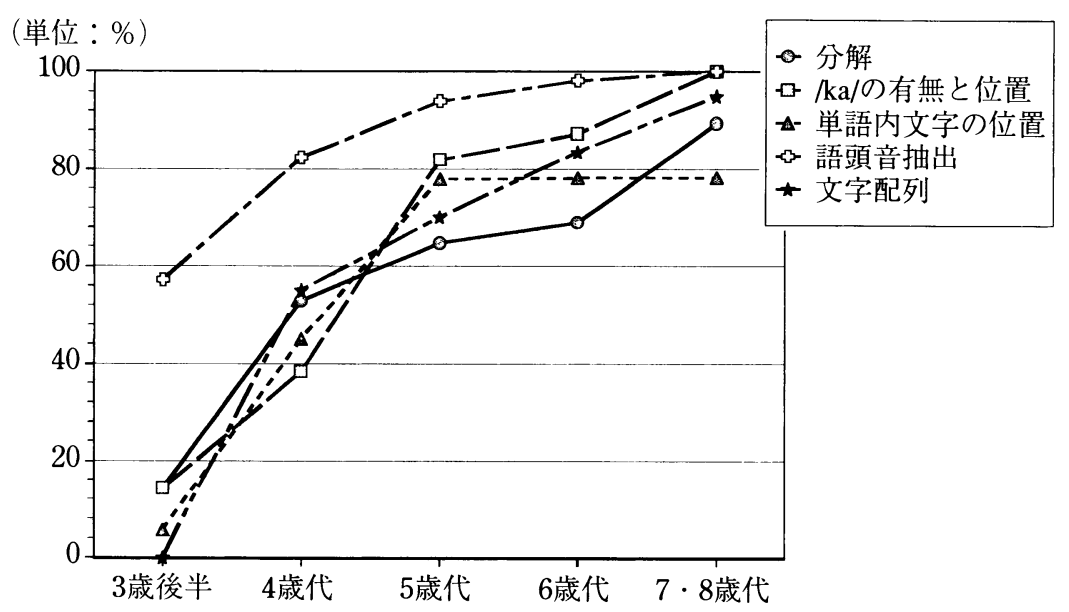

図 2 年齢別音韻操作能力検查平均正答率 
表 2 仮名読字課題における年齢間成績差検定結果（U 值）

\begin{tabular}{|c|c|c|c|c|c|c|c|c|c|}
\hline & 鏡映文字 & $\begin{array}{r}\text { 平仮名 } \rightarrow \\
\text { 片仮名 }\end{array}$ & $\begin{array}{l}\text { 片仮名 } \rightarrow \\
\text { 平仮名 }\end{array}$ & $\begin{array}{l}\text { 音読： } \\
\text { 単音 }\end{array}$ & $\begin{array}{c}\text { 単音聴覚文字 } \\
\text { matching }\end{array}$ & $\begin{array}{c}\text { 視覚的語彙 } \\
\text { 判定 }\end{array}$ & $\begin{array}{l}\text { 音読： } \\
\text { 文字の長さ }\end{array}$ & $\begin{array}{l}\text { 音読： } \\
\text { 心像性×頻度 }\end{array}$ & $\begin{array}{l}\text { 音読： } \\
\text { 非実在語 }\end{array}$ \\
\hline 3 歳後半 4 歳代 & $11.0^{* *}$ & 37.0 & 37.0 & $3.5^{* *}$ & $7.0^{* *}$ & 41.0 & $10.0^{* *}$ & $11.0^{* *}$ & $8.0^{* *}$ \\
\hline 4 歳代～ 5 歳代 & 31.5 & $32.5^{*}$ & 35.5 & 55.0 & 37.5 & $28.5^{*}$ & 58.0 & 53.0 & 48.0 \\
\hline 5 歳代～ 6 歳代 & 34.0 & 25.0 & 38.0 & $25.5^{*}$ & 38.5 & 27.0 & 27.0 & 27.0 & 47.0 \\
\hline 6 歳代 $\sim 7 \cdot 8$ 歳代 & 96.5 & 119.0 & 95.5 & $51.0^{* *}$ & $108.0^{*}$ & 97.5 & $96.5^{*}$ & $85.0^{*}$ & $73.0^{* *}$ \\
\hline
\end{tabular}

$\mathrm{p}<.01^{* *}, \mathrm{p}<.05^{*}$

表 3 音韻操作能力検查の年齢間成績差検定結果 (U 值)

\begin{tabular}{|c|c|c|c|c|c|}
\hline & 分解 & $\begin{array}{l}\text { / ka/の有無の } \\
\text { 判定と位置づけ }\end{array}$ & $\begin{array}{l}\text { 単語内文字の } \\
\text { 位置づけ }\end{array}$ & 語頭音抽出 & 文字配列 \\
\hline 3 歳後半～ 4 歳代 & $9.0^{* *}$ & 29.5 & 15.5 & $15.0^{*}$ & $7.0^{*}$ \\
\hline 4 歳代～ 5 歳代 & 45.0 & $21.5^{* *}$ & $29.0^{*}$ & 36.0 & 49.0 \\
\hline 5 歳代～ 6 歳代 & 49.0 & 47.0 & 52.0 & 41.0 & 33.5 \\
\hline 6 歳代 $\sim 7 \cdot 8$ 歳代 & $45.0^{* *}$ & $84.0^{* *}$ & 122.5 & $108.0^{*}$ & $74.0^{* *}$ \\
\hline
\end{tabular}

$\mathrm{p}<.01^{* *}, \mathrm{p}<.05^{*}$

\section{結果}

\section{1. 全検査正答率の発達による変化}

健常児の年齢群別項目別平均正答率において正答率 80 \%以上をその能力が獲得されたとみなすと，「単音 の聴覚文字マッチング」,「語頭音抽出」の 2 課題は 4 歳代に，「鏡映文字」，「平仮名 $\rightarrow$ 片仮名マッチング」, $\lceil$ 片仮名 $\rightarrow$ 平仮名マッチング」,「視覚的語彙判定」,「心 像性と頻度が統制された単語の音読」「「/ ka/の有無と 定位」,「文字の配列」の各課題は 6 歳代に獲得されて いた。また，「単音の音読」「文字の長さの変化による 単語の音読」,「非実在語の音読」は 7 ・ 8 歳代で獲得 されていた。しかし「単語内文字の定位」は，5歳代 より成績の変化はみられなかった(図 $1 ， 2$ )。

年齢別に正答率の比較を行い，各検査成績が大きく 変化する時期を検討するため, 前後年齢時期間におけ る差の検定を行うと表 $2 ， 3$ のと抢りであった。その 結果, 文字の視知覚的分析の機能をみる「鏡映文字の 検出課題」では， 3 歳後半と 4 歳代の間で有意差が認 められた。「平仮名 $\rightarrow$ 片仮名マッチング」では 5 歳代と 6 歳代の間で有意差が認められた。「片仮名 $\rightarrow$ 平仮名マ ッチング」では 6 歳代と 7 ・ 8 歳代の間で有意差が認 められた。「単音の音読」では 3 歳後半と 4 歳代の間, 5 歳代と 6 歳代の間および 6 歳代と 7 ・ 8 歳代の間, 「単音の聴覚文字マッチング」では 3 歳後半と 4 歳代の 間,「視覚的語彙判定」では，4歳代と 5 歳代の間およ び 6 歳代と 7 ・ 8 歳代の間,「文字の長さの変化による 単語の音読」では 3 歳後半と 4 歳代の間,「心像性と頻
度が統制された単語の音読」では 3 歳後半と 4 歳代の 間扔よび 5 歳代と 6 歳代の間, 「非実在語の音読」では 3 歳後半と 4 歳代の間および 6 歳代と 7 ・ 8 歳代の間, $\lceil モ ー ラ$ 分解」では 3 歳後半と 4 歳代の間おょび 6 歳代 と 7 ・8 歳代の間, 「/ka/の有無の判定と位置づけ」で は 4 歳代と 5 歳代の間および 6 歳代と 7 ・ 8 歳代の間 で有意差が認められた。「単語内文字の位置づけ」では 3 歳後半と 4 歳代の間抒よび 4 歳代と 5 歳代の間, 「語 頭音抽出」では 3 歳後半と 4 歳代の間, 「文字配列」で は 3 歳後半と 4 歳代の間および 6 歳代と 7 ・ 8 歳代の 間で有意差が認められた。

\section{2. 音韻操作能力検査における年齢間の相関}

さらに年齢別の音韻操作能力に関する項目に関して 検查成績間の発達による変化を検討するために年齢別 に各項目成績間の相関係数を算出した。「分解」と $\lceil/ \mathrm{ka} /$ の有無の判定と位置づけ」では 3 歳後半 $(\mathrm{r}=.84)$ 抢よび 6 歳代 $(r=.55)$ において高い相関が みられたが, 4 歳代 $(r=.19)$ おょび 5 歳代 $(\mathrm{r}=-.12)$ ではほとんど相関がみられなかった。「分 解」と「単語内文字の位置」では 3 歳後半 $(r=-.27)$ では負の相関， 4 歳代 $(r=.40)$ で正の相関, 5 歳代 $(\mathrm{r}=-.30)$ で,再び負の相関となり, 6 歳代 $(r=.50)$ で正の相関となっていた。 7 ・8歳代になるとほとん ど相関はみられなかった $(\mathrm{r}=.03)$.「分解」と「語頭 音抽出」では 3 歳後半 $(r=.20)$ から 6 歳代 $(\mathrm{r}=-.01)$ にかけて高い相関はみられなかった。「分 解」と「仮名の配列」では 4 歳代 $(r=.68)$ および 6 歳 代 $(r=.60)$ で中程度の相関がみられた。「/ka/の有無 


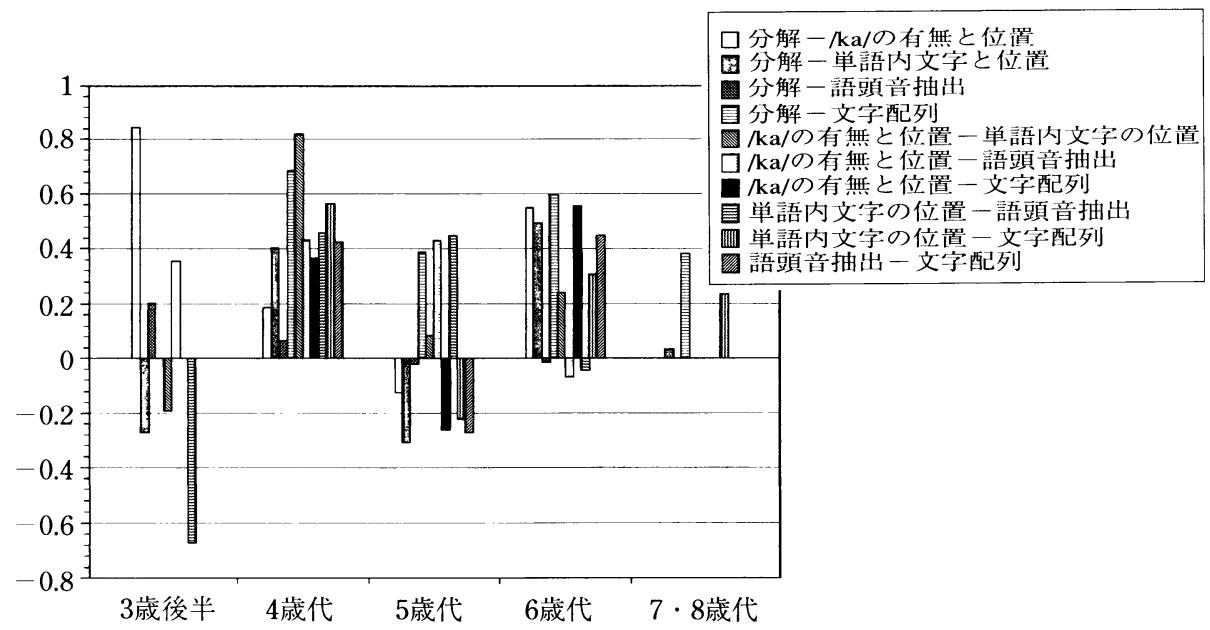

図 3 音韻操作能力検查における各課題間の相関

の判定と位置づけ」と「単語内文字の位置づけ」では 3 歳代 $(r=-.19)$ および 5 歳代 $(r=.09)$ でほとんど 相関がみられなかったが, 4 歳代 $(r=.82)$ で高い相関 がみられた。「/ ka/の有無の判定と位置づけ」と「語頭 音抽出」では 3 歳後半 $(r=.35)$ および 6 歳代 $(r=-.07)$ でほとんど相関がみられなかったが, 4 歳 代 $(r=.43)$ 抢よび 5 歳代 $(r=.43)$ で中程度の相関が みられた。「/ ka/の有無の判定と位置づけ」と「仮名の 配列」では 4 歳代 $(r=.36)$ および 5 歳代 $(r=-.26)$ で, 低い相関がみられ，6歳代 $(r=.55)$ でかなり高い 相関がみられた。「単語内文字の位置づけ」と「語頭音 抽出」では 3 歳後半 $(r=-.67)$ で高い負の相関, 4 歳 代 ( $r=.46)$ および 5 歳代 $(r=.45)$ で中程度の正の相 関, 6 歳代 $(r=-.05)$ ではほとんど相関はみられなか った.「単語内文字の位置づけ」と「仮名の配列」では 4 歳代 $(r=.57)$ で中程度の相関がみられた. 5 歳代 $(r=-.22)$ で負の相関, 6 歳代 $(r=.31), 7 \cdot 8$ 歳 代 $(r=.24)$ では正の相関を示し,「語頭音抽出」と「仮 名の配列」では 4 歳代 $(r=.43)$ およひ 6 歳代 $(r=.45)$ で中程度の相関がみられ, 5 歳代 $(r=-.27)$ で負の相関を示した（図 3 ).

\section{考察}

本研究は, 健常児の発達における音韻操作能力の獲 得過程とその獲得段階と読字能力との関係を検討する ことを目的とした. 本研究では, 発達過程を検討する ことを目的にしているが，各年齢における対象者数が 10 例程度と限定されている. 対象者数が限られている ものの, 本研究で得られた結果によると, 仮名読字過 程の検査により, 読字に必要な各過程の能力は, 年齢
の進行とともに変化し, 仮名読字過程が成立すること が明確となった. また, 音韻操作能力検査より, 分解・ 抽出・配列の各能力は年齢とともに変化していき, 就 学後は, これらの能力が独立していくことが明らかと なった。

1 ）仮名読みの獲得過程について

本研究においては, 仮名読字能力の獲得の程度, さ らに仮名読字能力獲得の順序性を知るために, 読字過 程に沿った検査を行った。 Whitworth ${ }^{7)}$ が示した読字 過程の各段階に沿って, 発達による各能力獲得の順序 性について検討した。

PALPA に基づいて作成した仮名読字検査の各項目 の正答率より，仮名読字過程の各成分の完成時期を検 討した。その結果，それぞれの検査項目において正答 率 $80 \%$ を基準として獲得, 未獲得の判定を行うと以下 のようであった. 3 歳後半から 5 歳代にかけては, 仮 名読字処理過程のいずれの成分の成績も獲得レベルに 達していなかった。 6 歳代になると仮名読字処理過程 の一部（正書法入力レキシコン, 意味システム) は獲 得レベルに達していた， $7 \cdot 8$ 歳代になると，仮名読字 過程のすべての成分で獲得レベルに達していた。

仮名読字過程各成分の獲得時期をまとめると, 視賞 的正書法分析能力は，文字として視覚的に認知する能 力であり, 3 歳後半で最初に獲得される能力といえる. 正書法一音韻変換は，3歳後半から逐字読みにより, 仮名文字と音との対応能力が獲得され始めていると考 えられ， 3 歳後半から 7 ・ 8 歳代にかけて獲得される と推測される。このように非実在語を音読する際に使 用されるといわれる視覚的正書法分析から正書法一音 韻変換が行われ, 直接スピーチに至る, 意味の活性化 
を介さない機能が 3 歳後半で存在していることが示唆 される. 次に 4 歳代から 6 歳代にかけて正書法入力レ キシコン, 意味システムの機能が獲得されると考えら れる。これにより，意味を活性化させる必要のある実 在語の場合に使用される視覚的正書法分析 $\rightarrow$ 正書法入 カレキシコン 意味システムのルートが 4 歳代には存 在していると考えられ, 読字の二重ルート構造が成立 していると推測された. また, 文字同定能力は, 仮名 の音韻規則を習得した 6 歳代に獲得されると考えられ た. 3 歳後半より徐々に獲得されていた視覚的正書法 分析から正書法一音韻変換のルートは 7 ・ 8 歳代にな り，仮名文字の獲得とともに完成されるといえる。

2 ）音韻操作能力の相互関係

音韻操作能力検查の正答率をみると,「単語内文字の 位置」を除き， 5 歳代から 7 ・ 8 歳代にかけ徐々に獲 得レベルに達している.さらに, 分解, 抽出, 文字配 列を含む音韻操作能力の年齢の進行による項目間の相 互関係については,「モーラ分解」と「/ ka/の有無の判 定と位置づけ」,「分解」と「語頭音抽出」を除く他の 項目間で，4歳代と 6 歳代において高い相関がみられ た.つまり， 3 歳後半では音韻操作の各能力は独立し た能力であったものが，4歳代になるとモーラ分解が 可能になり，単語の個々の音を同定することができ， さらに単語として音を合成できるという読み書きの一 連の流れが成立すると推測される。これは，4歳半頃 に音節の分解, 音韻の抽出という能力が獲得されると いう天野1)の知見と一致した結果であった。 その後, 5 歳代になると音韻操作の各能力はそれぞれ独立した能 力となり, 6 歳代になると再び読み書きの相互関連性 が成立する．さらに，仮名文字を獲得したと考えられ る 7 ・ 8 歳代になると音韻操作能力の各能力は独立し た能力となっていた。

以上に確認された仮名文字獲得の過程は，4歳代か ら 5 歳代にかけて 1 文字が 1 音に対応するという仮名 文字の法則の発見（「かなの発見」）をし，5歳代から ことばや文字は遊びの道具として働く $(\text { 首藤 } ： 1975)^{8)}$ と考えられる.

以上のような報告から， 5 歳代で音韻操作の各能力 間に相関がみられないことについて，5歳代になると 1 文字づつの処理から, 単語レベルの処理への移行期 であると推測される。

このように, 文字単語の分解, 抽出の能力が獲得さ れ始める 4 歳代より文字単語の 1 つ 1 つの音と文字の 対応が可能になると, 文字配列能力が獲得される. ま た， 6 歳代と 4 歳代で「分解」と「仮名の配列」,「/ ka/ の有無と位置」と「仮名の配列」,「単語内文字の位置」
と「仮名の配列」,「語頭音抽出」と「仮名の配列」の 項目間で高い相関がみられることにより, 仮名文字一 つ一つを結合し，意味を持った単語として認識してい ると推測される。これらは, phonological awareness の発達が 4 ・ 5 歳頃までの言語発達を土台として達成 される といわれていることと関係しているといえ る.

さらに，使用した検査項目には，仮名読字検査は文 字に関する課題, 音韻操作能力に関する課題 (分解, 抽出, 文字配列) は音韻に関する課題に分類される. データとして示してはいないが, 文字課題と音韻操作 能力を比較すると, 音読, 正書法一音韻変換能力と音 韻操作能力の成績には高い相関がみられ, 密な関係で あるという結果が得られた。これらの結果から, 読字 過程の各段階の能力を結びつけ, 一連の流れを形成さ せるために, 仮名文字を獲得するために音韻操作能力 の獲得は必要不可欠であるという先行研究 ${ }^{10,11)}$ の結果 と一致した.

さらに, 音韻操作能力に抢いて, 分解と抽出課題に 高い相関がみられ，それぞれの項目の誤りを検討した ところ, 促音を含んだ単語の分解・抽出課題で誤って いた単語は同様に促音を含んだ単語の配列課題でも誤 るなど, 各課題における誤りの文字特徵が一致してい る傾向がみられ, 分解・抽出能力の獲得の程度に配列 能力の獲得は依存していると考えられた.

読字には, 音韻に対する意識の獲得が必要不可欠で ある. 音韻操作能力が獲得されるとともに文字言語の 表記特徵を理解できるようになり, 単語としての認知 が可能になるといえる。

さらに, 仮名文字の習得が言語情報処理過程に及ほ す影響, 音韻と文字との関連性を明確にすることは, 仮名文字指導を行う上で重要であると考えられる。こ の点については, 対象者数を増やし, 今後の検討が必 要である.また, 言語障害や聴覚障害を持つ小児では, それぞれの小児に扔ける障害背景により, 本研究で得 られた健常児の発達過程と同様な過程をたどるかどう か明らかではない.この点に関しても今後の研究課題 であると思われる。

本稿の一部は第 44 回日本音声言語医学会総会 (1999 年, 福岡), 第 8 回言語障害臨床学術研究会（1999，東京）にて発表した.

\section{文献}

1）天野 清：語の音韻構造の分析とかな文字の読み の学習. 教育心理学研究, $18: 76-89,1970$.

2) 物井寿子 : 失語症の読み書き障害の訓練一仮名書 
字訓練を中心に一. 神経心理学, 6：33-40, 1990.

3) 天野 清：音韻分析と子どもの literacy の習得. 教育心理学年報, 第 27 集 : 142-164, 1987.

4）坂本龍生，吉村 宰: 情報処理的アプローチによ る読み障害児の認知過程に関する最近の研究動 向. 発達障害研究, $13: 50-61,1992$.

5) Kay, J., Lesser, R. and Coltheart, M : Psycholinguistic assessments of language processing in aphasia, 1992.

6）福迫陽子, 伊藤元信, 笹沼澄子：言語治療マニュ アル. 医歯薬出版, 東京, 55-57 頁, 1994.

7）Whitworth A.B.：英国における失語症の言語治 療一認知神経心理学的接近一. 講習会資料, 1997.

8）首藤久義：「読み」の学習と教育一メソッドの統合
の視点 $-\cdots$ 日本語の表記体系と子どもの学習・発 達過程に即して一。読書科学，19：69-85，1975.

9）大石敬子：言語発達障害における音韻の問題一読 み書き障害の場合.第 43 回日本音声言語医学会総 会 学術講演会予稿集, 44, 1998.

10）天野 清：子どもの文字の習得過程. 秋山書店, 東京, 1986 .

11）大六一志：モーラに対する意識はかな文字の読み 習得の必要条件か? 心理学研究, 66:253-260, 1995.

別刷請求先：テ 701-0193 倉敷市松島 288 川崎医療福祉大学感覚矯正学科 尾川亜希子 